\title{
Erectile difficulty
}

\section{Susan Quilliam}

\section{Background}

Erection difficulty - both problem and solution - often impacts on the couple as well as on the male patient. But where individual needs clash with partnership needs, how should professionals respond?

\section{Clinical scenario}

One of your male patients, a newly retired civil servant aged 59 years, is diagnosed with type 2 diabetes. As part of the consultation, he admits suffering from erectile dysfunction (ED) over the past 4 years, is delighted to learn that this may be treatable, and is prescribed sildenafil or similar.

Two weeks later, the man's wife comes to see you, very distressed. She is 55 years old and has been postmenopausal for 6 years, since which time her sexual desire has plummeted. She now actively shrinks from sex, penetrative and otherwise, and sees no reason to resume sexual activity with her husband - "We're far too old for that!" - even though she loves him and feels they have a very solid relationship.

Since the husband's diagnosis, he has been actively pressing her for sex, which she finds upsetting. She asks you as the clinician to de-prescribe sildenafil so that the couple can resume their previous stable and affectionate but not sexual - relationship. She claims that if you don't, she sees the marriage disintegrating.

\section{The panel}

A panel of five individuals- four health professionals and one layperson (detailed in Box 1) - were invited to give their views on how this case should be managed.

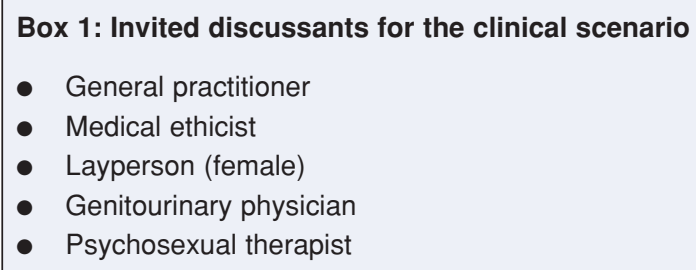

- General practitioner

- Medical ethicist

- Layperson (female)

- Genitourinary physician

- Psychosexual therapist

\section{General practitioner}

This is not an uncommon scenario! And for that reason, while in my practice we don't insist on partners or wives attending, in order prevent the situation, we do check with the man whether his partner is agreeable to his having treatment.

In this case I do feel that for the relationship to survive, it must try to meet the needs of both parties. I'd review the man initially by himself and then together with his wife, with the ultimate aim of getting them to compromise.

\section{J Fam Plann Reprod Health Care 2007; 33(1): 59-60}

\section{Cambridge, UK}

Susan Quilliam, BA, Cert Ed, MNLP, Freelance Writer, Broadcaster and Agony Aunt

Correspondence to: Ms Susan Quilliam.

E-mail: susan@susanquilliam.com

\section{Medical ethicist}

Imagine that a man comes into your surgery one day. He says that his wife refuses to give him a child and he wants you to de-prescribe the Pill. Would you agree? I hope not.

Conniving to get a woman pregnant is arguably more serious than conniving to reduce the erectile function of a postmenopausal woman's husband. But conniving it is, and this is not something that doctors should contemplate. Nor should they allow themselves to be held hostage to nonmedical consequences in this way.

The marriage, says the woman, is under threat. You, she implies, have the power to save it. You should point out that, given their 'solid relationship', there must be a good prospect of her and her husband sorting out their sexual differences. What is a solid relationship if not one in which problems can be addressed co-operatively? By all means offer to talk to the husband, but don't forget that he is a competent individual who can and should be involved in his own treatment plan.

\section{Layperson (female)}

It may be tempting in this situation to think of the woman as unreasonable, prudish and frigid - all things our highly sexualised society tells us women shouldn't be.

However, put yourself in her shoes for a moment. You have a companionate marriage - you're happy and you believe your husband is too. Then you're hit with the worrying bombshell that your husband has diabetes. But while you're still reeling, your comfy, predictable husband stops being comfy or predictable and starts wanting you to be a sex goddess for the first time in years. Understandably, you feel that your world is falling down around your ears - everything that was safe and secure is disrupted.

So, you pluck up your courage and do what we are always told to do if we are in trouble - you go and see your doctor. And what you need from that doctor - what your husband got in his consultation - is to have your problem taken seriously. The doctor may be technically unable to de-prescribe but he can, and should, address the problem with respect and as much support as he can offer.

\section{Genitourinary physician}

One of the key things this conundrum highlights is that while a couple's sex life is a true reflection of their relationship, so often they don't communicate about it.

Men in particular, I find, are bad at communication. They come into my surgery keen to regain their erection, keen to get medication that will give them back their sex life, but then they say that they don't want to tell their wives, that they just want to 'surprise' her with their newfound prowess. So this scenario is one I see regularly.

I would want the couple to come and see me together and attempt to find a solution that would work for them both. I would ask them to face up to the alternatives; if the wife insists that sex is going to be off the agenda that might not be a problem for the husband, but on the other hand there may be a real possibility he may go and get sex elsewhere.

I would see my role as being mainly to encourage the couple to face up to the choice they have to make and, most importantly, to communicate about it. After that, the decision is up to them. 


\section{Psychosexual therapist}

I wouldn't accommodate the wife's request, because what's happening here isn't about the medical issues of ED or about loss of interest; it's about an underlying relationship dynamic and that's what needs to be sorted out.

Almost certainly, husband and wife have recently had an unspoken agreement to be celibate but now that contract is shifting. He wants sex again. She's feeling utterly panicked and is trying to control the situation by denying him medication. If she succeeds, he'll be justifiably angry. If she doesn't, she'll be resentful. If the issues aren't addressed, then even if she gets what she wants, the marriage will disintegrate.

So my way forward would be to challenge both of them to enter therapy, explaining that if they don't then they could be throwing away decades of emotional investment.

If they agreed to therapy, I'd start with a couple assessment, then individual assessments focusing on sexual history, feelings of intimacy, their relationship prior to ED, their recent dynamics. The main question would be whether they want to stay together. If they do, my experience - from 16 years of practice - is that a programme of education and sensate focus could help them rediscover their sexuality, solving the problem at its source.

\section{Discussion}

While as health care professionals our patient is our first concern, it's always true that treatment has the potential to impact on the patient's wider life situation.

So while none of the panel believed that the wife's request should be accommodated, they all believed that the health professional should take a certain degree of responsibility for the situation and should take steps to alleviate it - not only for the husband's sake but also for his wife's. Interestingly, where the professionals on the panel diagnosed marital difficulty as being at the heart of the matter, they also took responsibility for helping the couple address that issue as well as the resolution of the strictly medical one.

In the end, there was no simple answer to this clinical conundrum. The moral, however, is surely that health care - like all physical and emotional therapies - is always systemic in nature. We forget that at our peril.

\section{Acknowledgements}

The author would like to thank the panel members for their input. A listing of the individual panel members who have contributed to the Clinical Conundrum section of the Journal is published annually.

\section{FACULTY MEMBERSHIP EXAMINATION}

The Membership Examination (MFFP) consists of:

$\square$ Part 1 Multiple Choice Question paper (MCQ)

This 11/2-hour paper consists of 50 clinical science and applied science questions.

The examination will be held in London on Friday 19 October 2007 (applications must be received by 1 July 2007). The application form and information on the Part 1 can be obtained from the Faculty of Family Planning website (www.ffprhc.org.uk).

\section{$\square$ Dissertation or Case Reports}

Submission of one Dissertation (10 000 words) or two Case Reports (3000 words each).

Please visit the Faculty of Family Planning website (www.ffprhc.org.uk) for the latest changes to this part of the examination, and for information on exemptions.

\section{$\square$ Part 2 Examination (CRQ, MEQ, OSCE)}

This all day examination consists of:

Critical Reading Question examination paper (CRQ)

Modified Essay Question examination paper (MEQ)

Objective Structured Clinical Examination (OSCE)

Applications for the MFFP Part 2 held on 14 June 2007 must be received by Wednesday 3 January 2007. Please consult the revised Examination Regulations for changes to the entry requirements. Information on the Part 2 examination and the application form appear on the Faculty of Family Planning website (www.ffprhc.org.uk).

The qualification is subject to re-certification every 5 years.

For the revised MFFP Examination Regulations (December 2005), information and application forms please visit the Faculty of Family Planning website: www.ffprhc.org.uk (see Training \& Exams and MFFP Member). Also available on request from: Mrs Denise Pickford, Examinations, Faculty of Family Planning and Reproductive Health Care of the Royal College of Obstetricians and Gynaecologists, 27 Sussex Place, Regent's Park, London NW1 4RG, UK. Tel: +44 (0) 2077245629. Fax: +44 (0) 207723 5333. E-mail: denise@ffprhc.org.uk 